\title{
ANALISIS TINGKAT KEBISINGAN PERALATAN PRODUKSI TERHADAP KINERJA KARYAWAN
}

\author{
HERI MUJAYIN KHOLIK DAN DIMAS ADJI KRISHNA \\ Jurusan Teknik Industri Universitas Muhammadiyah Malang \\ Laman: mujayinkholik@yahoo.co.id
}

\begin{abstract}
ABSTRAK
Penggunaan mesin dan alat kerja yang mendukung proses produksi berpotensi menimbulkan suara kebisingan. Kebisingan adalah terjadinya bunyi yang tidak dikehendaki sehingga mengganggu atau membahayakan kesehatan. Penelitian ini bertujuan untuk menganalisa pengaruh tingkat kebisingan terhadap kinerja karyawan. Pengumpulan data dilakukan dengan cara observasi langsung dan kuesioner kepada pekerja di beberapa titik sampling. Pengolahan data menggunakan uji t test untuk mengetahui tingkat kebisingan dan analisis regresi linier sederhana untuk mengetahui pengaruh tingkat kebisingan terhadap kinerja karyawan. Dari pengolahan data yang telah dilakukan dengan menggunakan uji t maka dapat ditarik kesimpulan bahwa level kebisingan di area kerja Power Plant II menunjukkan perbedaan yang signifikan dengan Nilai Ambang Batas (NAB) yang telah ditetapkan oleh pemerintah, yaitu sebesar 98,599 dB. Sedangkan $N A B$ yang telah ditetapkan oleh pemerintah untuk area kerja (Industri) adalah sebesar $85 \mathrm{~dB}$. Hasil analisis regresi menunjukkan diperoleh $t$ hitung sebesar 10,227 lebih besar dibandingkan t tabel sebesar 2,013. Nilai signifikansi juga sebesar 0 lebih kecil dibandingkan $\alpha$ sebesar 0,05. Hasil ini menunjukkan bahwa kebisingan di area kerja Power Plant II berpengaruh signifikan terhadap kinerja karyawan.
\end{abstract}

Kata kunci: kebisingan, peralatan produksi, regresi linier sederhana, kinerja karyawan

\begin{abstract}
Machines and tools was used to support the production process have the potential effect to cause noise. Noise is the unwanted sound that interfere and endanger health. This research aimed to analyze the effect of noise level on the performance of the employees. Data collection was done by doing direct observation and questionnaires to workers in some sampling points. Processing data using the t test to determine noise level and simple linear regression to determine the effect of noise level on employee performance. Conclusion from data processing it was known that the noise level in the work area Power Plant II showed significant differences with the Threshold Limit Value (TLV) set by the government namely $98.599 \mathrm{~dB}(\mathrm{~A})$, while TLV set by the government for the work area (Industry) is approximately $85 \mathrm{~dB}$ (A). Results of simple linear regression analysis indicate that the value of test was 10.227, this value was greater than t table namely 2.013. Value of significant level is 0.000 less than $\alpha$ 0.05. These results indicate that the noise in the work area Power Plant II had a significant impact on employee performance.
\end{abstract}

Key words: noise, machine and work tool, simple linear regression, employee performance

\section{PENDAHULUAN}

Kebisingan merupakan masalah yang sering dijumpai di banyak perusahaan besar saat ini. Penggunaan mesin dan alat kerja yang mendukung proses produksi berpotensi menimbulkan suara kebisingan. Kebisingan adalah terjadinya bunyi yang tidak dikehendaki sehingga mengganggu atau membahayakan kesehatan (Kepmenkes No.1405/MENKES/SK/XI/2002). Kebisingan dapat menyebabkan berbagai gangguan seperti gangguan fisiologis, gangguan psikologis, gangguan komunikasi dan ketulian. Ada yang menggolongkan gangguannya berupa gangguan Auditory, misalnya gangguan terhadap pendengaran dan gangguan non Auditory seperti gangguan komunikasi, ancaman bahaya keselamatan, menurunnya performa (kinerja), stress dan kelelahan. Kebisingan yang terjadi secara terus menerus dapat menimbulkan gangguan kesehatan dan ketidaknyamanan dalam bekerja. Gangguan yang ditimbulkan akibat kebisingan pada karyawan bermacam-macam, mulai dari gangguan fisiologis, gangguan psikologis, gangguan keseimbangan, gangguan komunikasi sampai pada gangguan permanen seperti kehilangan pendengaran (Nasri, 1997).

Karyawan merupakan aset organisasi yang sangat berharga dan merupakan unsur penting dalam proses produksi. Karena itu karyawan harus dijaga, 
dibina dan dikembangkan untuk meningkatkan produktifitasnya. Karyawan yang sehat berdampak pada proses produksi di perusahaan. Karyawan yang sehat akan mendukung proses produksi dapat berjalan dan berkembang lancar, berkesinambungan, tidak terganggu oleh kejadian kecelakaan. Karyawan yang sehat adalah faktor penentu yang vital untuk pertumbuhan perusahaan. Dharma (2003) mengemukakan bahwa rangsangan suara yang berlebihan atau tidak dikehendaki (bising), yang dijumpai diperusahaan akan mempengaruhi fungsi pendengaran. Berbagai faktor seperti intensitas, frekuensi, jenis atau irama bising, lama pemajanan serta antar waktu istirahat dalam dua periode pemajanan sangat menentukan dalam proses terjadinya ketulian atau kurang pendengaran akibat bising. Demikian juga faktor kepekaan tiap pekerja seperti misalnya umur, pemajanan kebisingan sebelumnya, kondisi kesehatan, penyakit telinga yang pernah diderita, perlu pula dipertimbangkan dalam menentukan gangguan pendengaran akibat bising.

Alat kerja dan mesin-mesin yang digunakan pada aktivitas kerja berpotensi menimbulkan suara bising. Hal ini berdampak negatif terhadap para pekerja yang berada di area tersebut, yang mendengarkan kebisingan selama jam kerja berlangsung setiap harinya. Apabila tidak diperhatikan akan berdampak pada kesehatan para pekerja sehingga berpengaruh terhadap kinerja karyawan. Mangkunegara (2000) menyatakan kinerja adalah hasil kerja secara kualitas dan kuantitas oleh seorang pegawai dalam melaksanakan tugasnya sesuai dengan tanggung jawab yang diberikan kepadanya. Kualitas yang dimaksud adalah kehalusan, kebersihan dan ketelitian dari segi hasil pekerjaan. Sedangkan kuantitas diukur dari jumlah pekerjaan yang diselesaikan karyawan. Selain itu kinerja juga dapat diartikan sebagai suatu hasil dari usaha seseorang yang dicapai dengan adanya kemampuan dan perbuatan dalam situasi tertentu. Sehingga kinerja tersebut merupakan hasil keterkaitan antara usaha, kemampuan dan deskripsi pekerjaan. Kinerja karyawan akan menurun apabila terganggu kesehatannya dan merasa tidak aman dalam bekerja.

\section{METODE}

Penelitian dilakukan pada area kerja Power Plant II PT PERTAMINA (Persero) Refinery Unit V Balikpapan. Metode yang digunakan untuk mengumpulkan data dilakukan dengan 3 cara yaitu dengan Studi Lapangan (observasi), wawancara dan kuisioner. Observasi dilakukan guna mendapatkan data kebisingan pada tiap lantai di area kerja Power Plant II Pertamina RU V Balikpapan. Wawancara dilakukan kepada pekerja Pertamina di bagian Utilities (Power Plant II) guna mendapatkan data-data yang diperlukan seperti jumlah karyawan, Peraturan HSE (Health, Safety, Enviromental) di lingkungan Pertamina RU V dan informasi lokasi yang berpotensi bising. Sedangkan kuisioner diberikan kepada pekerja Pertamina yang berhubungan dengan peralatan produksi untuk mengetahui apakah ada pengaruh kebisingan terhadap kinerja pekerja.

Data yang digunakan pada penelitian ini meliputi data tingkat kebisingan, yang didapatkan dengan melakukan pengukuran tingkat kebisingan dengan bantuan alat Sound Level Meter 'NICETY' SL811 dengan jarak pengukuran 0,5 - 1 meter dari titik sampling pengukuran. Titik sampling ini dipilih karena memiliki potensi kebisingan yang cukup tinggi, dimana banyak mesin - mesin yang beroperasi 24 jam tanpa henti. Adapun mesin tersebut seperti Turbine Generator, Boiler Feed Water, Air Cooler Turbine Generator, Condensate Pump Turbine Generator, hingga Deaerator. Selanjutnya dilakukan pengumpulan data melalui kuesioner yang disebar pada 50 orang karyawan guna mengetahui seberapa besar pengaruh kebisingan terhadap kinerja karyawan yang berada di area kerja Power Plant II.

Uji t digunakan untuk menguji apakah level kebisingan di area kerja Power Plant II Pertamina RU V Balikpapan sudah sesuai standar yang ditetapkan yaitu sebesar $85 \mathrm{~dB}$ (A). Ambang batas keamanan yang direkomendasikan oleh Occupational Safety and Health Admistration (OSHA) dan Organisasi Kesehatan Dunia (WHO) dan mengacu pada Keputusan Menteri Karyawan No. KEP-51/ MEN/1999, tentang baku mutu tingkat kebisingan, yaitu intensitas bising rata-rata tidak lebih dari 85 $\mathrm{dB}$ (A) selama 8 jam per hari atau 40 jam per minggu. Rumus uji t yang digunakan adalah sebagai berikut (Sugiyono,2007):

$$
t=\frac{\bar{x}-\mu}{\frac{s}{\sqrt{n}}}
$$

\section{Keterangan: \\ $\bar{x}:$ rata-rata $\mathrm{x}$ \\ $\mu$ : nilai yang dihipotesiskan \\ $\mathrm{s}$ : simpangan baku \\ $\mathrm{n}$ : jumlah anggota sampel}

Apabila diperoleh $\mathrm{t}$ hitung lebih besar $\mathrm{t}$ tabel maka $\mathrm{H}_{0}$ ditolak. Sebaliknya, apabila t hitung lebih kecil sama dengan $\mathrm{t}$ tabel maka $\mathrm{H}_{0}$ diterima. Bila 
$\mathrm{H}_{0}$ ditolak berarti ada perbedaan signifikan level kebisingan di area kerja Power Plant II Pertamina RU V Balikpapan dengan standar yang ditetapkan, yaitu $85 \mathrm{~dB}(\mathrm{~A})$.

Variabel-variabel yang digunakan untuk kuesioner pada penelitian ini beserta definisi operasionalnya adalah sebagai berikut: Variabel Bebas (X) pada penelitian ini adalah kebisingan (X). Sedangkan, Variabel Terikat (Y) pada penelitian ini adalah kinerja karyawan (Y). Indikator dan item pertanyaan masing-masing variabel disajikan pada Tabel 1.

Skala pengukuran yang digunakan untuk mengukur variabel kebisingan dan kinerja karyawan menggunakan skala Likert (Umar, 2001). Dengan penentuan penilaian skor sebagai berikut: jawaban sangat tidak setuju diberi skor 1, jawaban tidak setuju diberi skor 2 , jawaban cukup setuju diberi skor 3 , jawaban setuju diberi skor 4 dan jawaban sangat setuju diberi skor 5 .

Setelah diperoleh jawaban dari responden pada kuesioner yang telah disebar, maka data kebisingan dan kinerja karyawan diuji validitas dan reliabilitas guna mengetahui apakah item kuesioner yang digunakan sudah valid atau tidak dan apakah instrumen tersebut dapat dipercaya untuk dapat digunakan sebagai alat untuk mengukur atas variabel-variabel yang diteliti. Variabel dapat dikatakan valid apabila mempunyai $r$ hitung yang lebih besar dibandingkan $r$ tabel atau signifikan lebih kecil dibandingkan $\alpha$ sebesar 0,05. Sedangkan dikatakan reliabel jika nilai Alpha Cronbach yang didapatkan lebih besar dari 0,6 (Ghozali,2002)

Hasil kuesioner tersebut kemudian dianalisis dengan menggunakan analisis regresi linier sederhana untuk mengetahui pengaruh kebisingan terhadap kinerja karyawan. Untuk pengolahan data analisis regresi menggunakan bantuan software SPSS.

\section{HASIL DAN PEMBAHASAN}

Berdasarkan hasil pengukuran tingkat kebisingan, kemudian dilakukan perhitungan dengan uji t untuk mengetahui tingkat kebisingan yang ada diperusahaan untuk dibandingkan dengan standar kebisingan yang telah ditetapkan oleh pemerintah sebesar $85 \mathrm{~dB}(\mathrm{~A})$. Nilai rata-rata pada hasil pengolahan data menunjukkan bahwa rata-rata pengukuran kebisingan di area kerja Power Plant II sebesar 98,599 dB (A). Hasil perhitungan didapatkan hasil seperti pada Tabel 2 .

Tabel 2. Hasil Uji t

\begin{tabular}{cccc}
\hline t hitung & t tabel & Signifikansi & Keterangan \\
\hline 62,304 & 1,96 & 0,000 & Berbeda \\
\hline
\end{tabular}

Melalui uji t dapat diketahui bahwa t hitung sebesar 62,304 lebih besar dibandingkan t tabel sebesar 1,96 atau nilai sig. sebesar 0 lebih kecil dibandingkan $\alpha$ sebesar 0,05 . Hal ini menunjukkan bahwa level kebisingan di area kerja Power Plant II di atas rata-rata level kebisingan yang telah ditetapkan oleh pemerintah yaitu sebesar 85 , dan secara statistik perbedaan itu signifikan. Nilai Ambang Batas (NAB) kebisingan telah direkomendasikan menurut ACGIH dan ISO (International Standart Organization) sebesar $85 \mathrm{~dB}$ (A) sedangkan menurut OSHA (Occupational Safety and Health Assosiation) sebesar $90 \mathrm{~dB}$ (A) untuk waktu kerja 8 jam sehari dan 40 jam seminggu (Prabu, 2009). Sedangkan Imansyah (2006) menyatakan bahwa tingkat maksimal yang dapat didengar telinga manusia adalah $130 \mathrm{~dB}(\mathrm{~A})$, walaupun dianjurkan sebaiknya manusia jangan

Tabel 1. Variabel, Indikator, dan Item Pernyataan

\begin{tabular}{|c|c|c|}
\hline Variabel & Indikator & Item Pernyataan \\
\hline \multirow[t]{3}{*}{ Kebisingan (X) } & 1. Gangguan Psikologis & $\begin{array}{l}\text { a. Mudah kaget } \\
\text { b. Kurang konsentrasi } \\
\text { c. Mudah lelah } \\
\text { d. Cepat marah }\end{array}$ \\
\hline & 2. Gangguan Komunikasi & $\begin{array}{l}\text { a. Sering berteriak di area kerja bila berkomunikasi } \\
\text { b. Sering terjadi salah komunikasi di area kerja }\end{array}$ \\
\hline & 3. Gangguan Fisiologis & $\begin{array}{l}\text { a. Pendengaran kurang jelas } \\
\text { b. Mudah pusing/sakit kepala } \\
\text { c. Mual } \\
\text { d. Sesak nafas }\end{array}$ \\
\hline \multirow[t]{3}{*}{ Kinerja Karyawan (Y) } & 1. Kuantitas & $\begin{array}{l}\text { a. Kemampuan menyelesaikan pekerjaan sesuai target yang dibebankan } \\
\text { b. Dapat menyelesaikan pekerjaan dengan hasil yang konsisten sesuai standar }\end{array}$ \\
\hline & 2. Kualitas & $\begin{array}{l}\text { a. Kualitas kerja sesuai standar kualitas yang ditetapkan } \\
\text { b. Ketelitian dalam melakukan pekerjaan }\end{array}$ \\
\hline & 3. Waktu & $\begin{array}{l}\text { a. Ketepatan penyelesaian tugas dengan target waktu yang ditetapkan } \\
\text { b. Kekonsistenan waktu dalam menyelesaikan pekerjaan }\end{array}$ \\
\hline
\end{tabular}


sampai dihadapkan pada tingkat suara setinggi itu. Intensitas suara 90-95 dB (A) dapat merusak pendengaran. Tingkat kebisingan yang dialami secara terus menerus oleh karyawan di area kerja Power Plant II dapat mengganggu kesehatan, kenyamanan, serta dapat menimbulkan ketulian bagi para karyawan.

Data hasil kuesioner karyawan kemudian dilakukan pengujian validitas dan reliabilitas masingmasing variabel penelitian. Pengujian ini dilakukan sebagai langkah awal untuk mengetahui apakah data kuesioner yang sudah didapatkan tersebut bisa diproses untuk pengolahan data selanjutnya. Pengujian ini dilakukan dengan menggunakan software SPSS dan hasilnya dapat dilihat pada Tabel 3 dan Tabel 4.

Tabel 3. Rekapitulasi Uji Validitas dan Reliabilitas Variabel Kebisingan (X)

\begin{tabular}{ccccc}
\hline Hubungan & $\begin{array}{c}\text { Koefisien } \\
\text { Korelasi } \\
\text { (r hitung) }\end{array}$ & r tabel & Sig. & Keterangan \\
\hline X1 - X & 0,663 & 0,279 & 0,000 & Valid \\
X2 - X & 0,583 & 0,279 & 0,000 & Valid \\
X3 - X & 0,815 & 0,279 & 0,000 & Valid \\
X4 - X & 0,661 & 0,279 & 0,000 & Valid \\
X5 - X & 0,599 & 0,279 & 0,000 & Valid \\
X6 - X & 0,676 & 0,279 & 0,000 & Valid \\
X7 - X & 0,676 & 0,279 & 0,000 & Valid \\
X8 - X & 0,508 & 0,279 & 0,000 & Valid \\
X9 - X & 0,524 & 0,279 & 0,000 & Valid \\
X10 - X & 0,574 & 0,279 & 0,000 & Valid \\
\hline Nilai alpha cronbach $=0,8290$ & & Reliabel \\
\hline
\end{tabular}

Berdasarkan hasil pengujian yang disajikan pada Tabel 3 dapat disimpulkan bahwa semua item pada variabel kebisingan $(\mathrm{X})$ valid, karena hubungan antar skor tiap item dengan skor total mempunyai $r$ hitung yang lebih besar dibandingkan $\mathrm{r}$ tabel atau signifikan lebih kecil dibandingkan $\alpha$ sebesar 0,05. Sedangkan nilai alpha cronbach yang didapatkan sebesar 0,8290 lebih besar dari 0,6 sehingga variabel kebisingan (X) dapat dikatakan reliabel.

Tabel 4. Rekapitulasi Uji Validitas dan Reliabilitas Variabel Kinerja Karyawan (Y)

\begin{tabular}{ccccc}
\hline Hubungan & $\begin{array}{c}\text { Koefisien } \\
\text { Korelasi } \\
\text { (r hitung) }\end{array}$ & r tabel & Sig. & Keterangan \\
\hline Y1 - Y & 0.857 & 0.279 & 0.000 & Valid \\
Y2 - Y & 0.912 & 0.279 & 0.000 & Valid \\
Y3 - Y & 0.892 & 0.279 & 0.000 & Valid \\
Y4-Y & 0.788 & 0.279 & 0.000 & Valid \\
Y5 - Y & 0.849 & 0.279 & 0.000 & Valid \\
Y6 - Y & 0.883 & 0.279 & 0.000 & Valid \\
\hline \multicolumn{7}{l}{ Nilai alpha cronbach $=0.9245$} & & Reliabel \\
\hline
\end{tabular}

Berdasarkan hasil pengujian pada Tabel 4 dapat disimpulkan bahwa semua item pada variabel kinerja karyawan $(\mathrm{Y})$ valid, karena hubungan antar skor tiap item dengan skor total mempunyai $r$ hitung yang lebih besar dibandingkan $r$ tabel atau nilai signifikan lebih kecil dibandingkan $\alpha$ sebesar 0,05 . Sedangkan nilai alpha cronbach yang didapatkan sebesar 0,9245 lebih besar dari 0,6 sehingga variabel kinerja karyawan (Y) dapat dikatakan reliabel.

Berdasarkan data melalui kuesioner yang disebar pada 50 orang karyawan guna mengetahui seberapa besar pengaruh kebisingan terhadap kinerja karyawan yang berada di area kerja Power Plant II. Dari hasil kuesioner didapatkan hasil bahwa terdapat gangguan pada indikator psikologis, indikator komunikasi dan indikator fisikologis akibat kebisingan. Pada indikator gangguan psikologis, mayoritas responden menyatakan sangat setuju bahwa kebisingan yang ditimbulkan alat kerja dan mesin di wilayah kerja membuat responden menjadi orang yang mudah kaget, membuat kurang konsentrasi, membuat mudah lelah dan membuat cepat marah. Pada indikator gangguan komunikasi, mayoritas responden menyatakan sangat setuju bahwa kebisingan yang ditimbulkan alat kerja dan mesin di wilayah kerja membuat responden sering berteriak di area kerja bila berkomunikasi, dan sering terjadi salah komunikasi. Pada indikator gangguan fisikologis, mayoritas responden menyatakan setuju dan sangat setuju bahwa kebisingan yang ditimbulkan alat kerja dan mesin di wilayah kerja membuat pendengaran responden kurang jelas, mudah pusing/sakit kepala, sering mual, dan sering sesak nafas. Hal ini didukung oleh penelitian Fiedihal (2007) yang menyatakan bahwa kebisingan dapat mempengaruhi faktor psikologis, komunikasi dan fisikologis.

Kinerja karyawan dilihat dari beberapa indikator yaitu indikator kuantitas, kualitas dan waktu. Pada indikator kuantitas, mayoritas responden menyatakan cukup setuju bahwa responden mampu menyelesaikan pekerjaan sesuai target, dan tidak setuju bahwa responden mampu menyelesaikan pekerjaan dengan hasil yang konsisten sesuai standar. Hal ini menunjukkan bahwa kinerja karyawan di area kerja Power Plant II dalam segi kuantitas masih kurang baik. Hal in disebabkan karena pengaruh kebisingan yang setiap hari mereka alami mengganggu konsentrasi karyawan dalam menyelesaikan pekerjaan, sehingga pekerjaan yang dihasilkan tidak sesuai target dan tidak konsisten.

Pada indikator kualitas, mayoritas responden menyatakan cukup setuju bahwa kualitas kerja yang dihasilkan sudah sesuai dengan standar kualitas yang ditetapkan perusahaan, dan responden 
selalu teliti dalam melakukan pekerjaan. Hal ini menunjukkan bahwa kinerja karyawan di area kerja Power Plant II dalam segi kualitas cukup baik. Kebisingan yang mereka alami setiap hari, meskipun mengganggu konsentrasi karyawan, tetapi karyawan berusaha mempertahankan kualitas kerja. Pada indikator waktu, mayoritas responden menyatakan tidak setuju bahwa responden selalu menyelesaikan tugas sesuai dengan target waktu yang diberikan, dan waktu responden dalam menyelesaikan pekerjaan selalu konsisten. Hal in disebabkan karena pengaruh kebisingan yang setiap hari mereka alami mengganggu aktifitas karyawan dalam bekerja sehingga karyawan cenderung suka menunda pekerjaan, dan mengakibatkan tertundanya waktu penyelesaian pekerjaan.

Sebelum dilakukan analisa regresi sederhana untuk mengetahui pengaruh kebisingan terhadap kinerja karyawan, tahap selanjutnya adalah melakukan beberapa uji asumsi klasik diantaranya uji normalitas, uji multikolonieritas dan uji heteroskedastisitas. Pengujian normalitas data ini lakukan dengan tujuan untuk menguji apakah dalam model regresi, variabel penganggu atau residual memiliki distribusi normal. Pengujian normalitas data dalam penelitian ini menggunakan uji Kolmogorof Smirnov dan hasilnya ditampilkan pada Tabel 5. Berdasarkan Tabel 5, dapat diketahui bahwa nilai sig. yang dihasilkan lebih besar dibandingkan $\alpha$ sebesar 0,05, sehingga dapat disimpulkan bahwa data hasil kuesioner menyebar normal.

Tabel 5. Hasil Uji Normalitas Data

\begin{tabular}{ccc}
\hline Kolmogorof Smirnov & sig. & Keterangan \\
\hline 0,740 & 0,644 & Normal \\
\hline
\end{tabular}

Pengujian multikolinieritas bertujuan untuk menguji apakah model regresi ditemukan adanya korelasi antar variabel bebas. Hasil pengujian multikolinieritas pada masing-masing variabel bebas disajikan pada Tabel 6. Berdasarkan hasil pada Tabel 6 dapat diketahui bahwa nilai VIF variabel bebas lebih kecil dibandingkan 10, sehingga dapat disimpulkan bahwa tidak ada multikolonieritas antar variabel bebas dalam model regresi.

Tabel 6. Hasil Uji Multikolinieritas

\begin{tabular}{ccc}
\hline Variabel Bebas & VIF & Keterangan \\
\hline $\mathrm{X}$ & 1,000 & non multikolinieritas \\
\hline
\end{tabular}

Uji heteroskedastisitas bertujuan menguji apakah dalam model regresi terjadi ketidaksamaan variance dari residual satu pengamatan ke pengamatan yang lain. Hasil pengujian heteroskedastisitas dengan menggunakan scatter plot disajikan pada Gambar 1. Gambar scatter plot menunjukkan bahwa titik-titik menyebar secara acak serta tersebar baik diatas maupun dibawah angka 0 pada sumbu Y. Hal ini dapat disimpulkan bahwa tidak terjadi heteroskedastisitas pada model regresi sehingga model regresi layak dipakai untuk mengetahui pengaruh tingkat kebisingan terhadap kinerja karyawan.

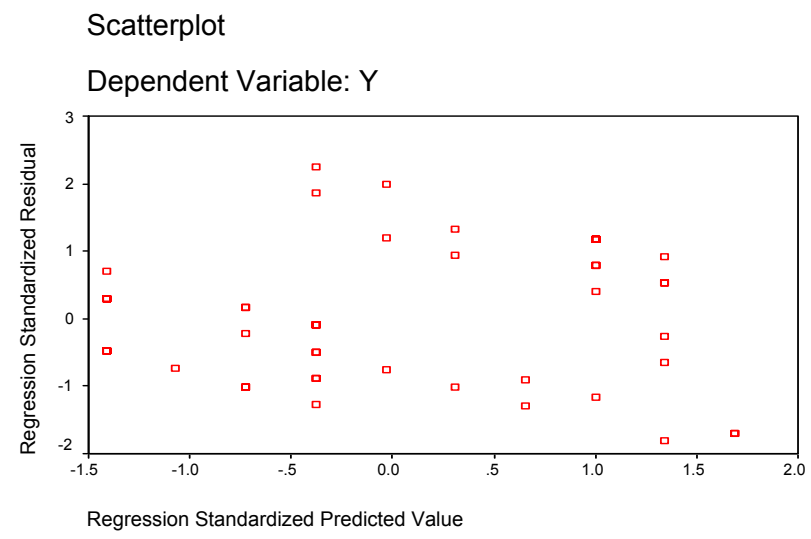

Gambar 1. Hasil Pengujian Heteroskedastisitas dengan Menggunakan Scatter Plot

Setelah memenuhi ketiga uji asumsi tersebut, maka dapat dilakukan analisis regresi linier sederhana. Pada penelitian ini analisis regresi linier sederhana dilakukan dengan menggunakan software SPSS. Hasil pengujiannya ditampilkan pada Tabel 7 .

Tabel 7. Rekapitulasi Hasil Uji Analisis Regresi Linier Sederhana

\begin{tabular}{lccccc}
\hline Variabel & $\begin{array}{c}\text { Koefisien } \\
\text { Regresi }\end{array}$ & $\begin{array}{c}\mathbf{t} \\
\text { hitung }\end{array}$ & $\begin{array}{c}\mathbf{t} \\
\text { tabel }\end{array}$ & Sig. & Keterangan \\
\hline Konstanta & 47,156 & & & & \\
$\mathrm{X}$ & $-0,679$ & 5,391 & 2,013 & 0,000 & Tolak Ho \\
\hline R & & 0,614 & & & \\
$R$ Square & & 0,377 & & & \\
F hitung & 29,059 & & & \\
F tabel (1,48; 0.05) & 4,04 & & & \\
Sig. & 0,000 & & & \\
\hline
\end{tabular}

Berdasarkan Tabel 7 dapat dilihat bahwa koefisien korelasi (R) sebesar 0,614 menunjukkan bahwa hubungan antara variabel kebisingan (X) terhadap variabel kinerja karyawan (Y) kuat. Besarnya sumbangan variabel kebisingan (X) terhadap variabel kinerja karyawan (Y) dapat dilihat dari $R$ Square sebesar 0,377 atau 37,7\%. Angka tersebut menunjukkan bahwa kebisingan $(\mathrm{X})$ yang digunakan dalam persamaan regresi ini memberikan kontribusi terhadap variabel kinerja karyawan (Y) sebesar $37,7 \%$. Sedangkan sisanya yaitu $62,3 \%$ 
merupakan kontribusi dari variabel lain yang tidak masuk dalam penelitian ini.

Melalui hasil pengolahan data kebisingan dan kinerja karyawan dengan menggunakan analisis regresi linier sederhana dihasilkan persamaan regresi linier. Persamaan regresi linier sederhana pengaruh kebisingan terhadap kinerja karyawan pada output SPSS dapat dilihat melalui Unstandardized Coefficients B dan persamaan yang dihasilkan adalah sebagai berikut:

$$
\mathrm{Y}=47,156-0,679 \mathrm{X}
$$

Intercept yang didapatkan sebesar 47,156 dan bernilai positif. Hal ini menunjukkan bahwa apabila tidak ada kebisingan di area Power Plant II PT. PERTAMINA (Persero) Refinery Unit V, maka kinerja karyawan sebesar 47,156. Nilai 47,156 menunjukkan bahwa rata-rata kinerja karyawan sudah baik apabila tidak ada gangguan kebisingan yang ada di area kerja mereka.

Koefisien regresi variabel kebisingan (X) sebesar - 0,679, yang berarti bahwa variabel kebisingan (X) memberikan pengaruh negatif terhadap kinerja karyawan (Y). Hal itu juga menunjukkan bahwa setiap peningkatan kebisingan, maka kinerja karyawan di area Power Plant PT. PERTAMINA (Persero) Refinery Unit $\mathrm{V}$ akan menurun sebesar 0,679 . Angka ini menunjukkan bahwa adanya kebisingan yang mengganggu di area Power Plant PT. PERTAMINA (Persero) Refinery Unit $\mathrm{V}$ mempengaruhi penurunan kinerja karyawan. Sebaliknya apabila kebisingan yang terjadi dapat diturunkan maka kinerja karyawan akan cenderung mengalami peningkatan.

Berdasarkan hasil pengujian analisis regresi linier sederhana melalui uji t, diperoleh $t$ hitung sebesar 10,227 lebih besar dibandingkan $t$ tabel sebesar 2,013 atau angka sig. sebesar 0 lebih kecil dibandingkan $\alpha$ sebesar 0,05 sehingga H0 ditolak. Dengan demikian dapat disimpulkan bahwa kebisingan (X) berpengaruh signifikan terhadap kinerja karyawan (Y). Hal ini menunjukkan bahwa apabila kebisingan di area kerja Power Plant II meningkat, maka kinerja karyawan akan menurun. Begitupun sebaliknya apabila kebisingan di area kerja Power Plant II menurun, maka kinerja karyawan akan meningkat. Hanifah (2006) dalam penelitiannya mengemukakan ada hubungan yang signifikan antara kebisingan dengan kelelahan dan pengaruh yang signifikan antara kebisingan terhadap kelelahan karyawan.

Kebisingan yang dialami oleh para karyawan memberikan dampak pada kinerja karyawan yang cenderung menurun karena terganggu dengan tingkat kebisingan yang sudah melampaui standard rata-rata yang telah ditetapkan oleh pemerintah.
Faktor kebisingan di lingkungan kerja berpengaruh terhadap kinerja karyawan. Dalam usaha mendapatkan kinerja karyawan yang tinggi, maka faktor kebisingan harus diperhatikan, agar sesuai dengan batasan kemampuan pendengaran. Hidayah dkk. (2007) dalam penelitiannya mengemukakan bahwa kebisingan mempengaruhi produktivitas operator. Dengan semakin tinggi tingkat kebisingan maka akan menurunkan tingkat produktivitas.

\section{SIMPULAN}

Dari pengolahan data yang telah dilakukan dengan menggunakan uji t maka dapat ditarik kesimpulan bahwa level kebisingan di area kerja Power Plant II menunjukkan perbedaan yang signifikan dengan Nilai Ambang Batas (NAB) yang telah ditetapkan oleh pemerintah, yaitu sebesar 98,599 dB (A). Sedangkan NAB yang telah ditetapkan oleh pemerintah untuk area kerja (Industri) adalah sebesar 85 dB (A). Hasil analisis regresi linier sederhana menunjukkan bahwa kebisingan di area kerja Power Plant II berpengaruh signifikan terhadap kinerja karyawan. Hal ini ditunjukkan dari hasil pengujian analisis regresi linier sederhana melalui uji t, diperoleh t hitung sebesar 10,227 lebih besar dibandingkan $t$ tabel sebesar 2,013 atau angka sig. sebesar 0 lebih kecil dibandingkan $\alpha$ sebesar 0,05 . Kebisingan pada area kerja juga memberikan beberapa efek Hasil ini mendukung beberapa penelitian terdahulu mengenai pengaruh tingkat kebisingan terhadap kinerja karyawan.

\section{DAFTAR PUSTAKA}

Dharma, A., 2003. Manajemen Personalia. Edisi Ketiga, Penerbit Erlangga. Jakarta.

Feidihal, 2007. Tingkat Kebisingan dan Pengaruhnya terhadap Mahasiswa di Bengkel Teknik Mesin Politeknik Negeri Padang. Jurnal Teknik Mesin, 4 (1), ISSN 1829-8958.

Ghozali, I., 2002. Aplikasi Analisis Multivariate dengan Program SPSS. Penerbit Universitas Diponegoro. Semarang.

Hanifa, T.Y.U., 2006. Pengaruh Kebisingan terhadap Kelelahan pada Tenaga Kerja Industri Pengolahan Kayu Brumbung Perum Perhutani Semarang. Skripsi. Universitas Negeri Semarang.

Hidayah, N.Y., Latifah D., dan Ratih W., 2011. Analisis Pengaruh Faktor Kebisingan dan Tingkat Kesulitan Kerja terhadap Produktivitas Line Assembling PT. X http://image.tsubaku.multiply.multiplycontent. com/. Diakses 16 Oktober 2011.

Imansyah, B.S dan Achmad R.D., 2006. Bising Ancam Pendengaran. Pikiran Rakyat. Bandung.

Kementerian Tenaga Kerja, 1999. Keputusan Menteri Tenaga Kerja Nomor Kep-51/MEN/1999 tentang Batas Kebisingan Maksimum dalam Area Kerja. 
Mangkunegara, 2000. Manajemen Sumber Daya Manusia Perusahaan. Cetakan Kedua. PT. Remaja Rosdakarya, Bandung.

Nasri, 1997. Teknik Pengukuran dan Pemantauan Kebisingan di Tempat Kerja.

Prabu, 2009. Dampak Kebisingan terhadap Kesehatan. http://putraprabuwordpress.com/2009/01/02/ pengukuran-nilai-ambangdan-zona-kebisingan/ Diakses 16 Oktober 2011.

Sugiyono, 2007. Statistika untuk Penelitian. Cetakan keduabelas. Alfabeta. Bandung.

Umar, H., 2001. Riset Sumber Daya Manusia. PT. Gramedia Pustaka Utama. Jakarta. 